\title{
Gravitation Auger Water Separator from a Suspension of Wet Bulk Material
}

\author{
Leopold Hrabovský ${ }^{*}$, Antonín Durna ${ }^{2}$, Jiří Fries ${ }^{2}$, Jiří Režnar ${ }^{3}$ \\ 1 VSB Technical University of Ostrava, Faculty of Mechanical Engineering, Institute of Transport, 17. listopadu \\ 2172/15, 70800 Ostrava - Poruba, Czech Republic, leopold.hrabovsky@vsb.cz \\ 2 VSB Technical University of Ostrava, Faculty of Mechanical Engineering, Department of Production Machines \\ and Design, 17. listopadu 2172/15, 70800 Ostrava - Poruba, Czech Republic \\ 3 Advanced Metal Powders s.r.o., Sládkova 372/8, 70200 Moravská Ostrava \\ *Corresponding autor's e-mail: leopold.hrabovsky@vsb.cz
}

\begin{abstract}
The paper deals with the problem of water separation from a mixture of wet loose material using a worm, or auger, dewaterer, whose working element is a full auger with variable thread pitch, rotating in a fixed trough. The extrusion of water from the wet material suspension, consisting of a mixture of mineral wool tufts and granules, is effected in the auger dewaterer by entraining and compressing the wet bulk material through the threads, the varied pitch of the conical screw, and the rotation of the auger.The thread faces and thread edges of an improperly designed screw of the auger dewaterer by Advanced Metal Powders s.r.o. showed notable wear from the applied pressure of the packed wet bulk material (passing through the threads of the different pitch of the conical auger). Finding the cause of the severe abrasion and preventing excessive further wear of the auger was the subject of theoretical calculations and experimental verification tests, whose main conclusions are presented in this paper. The paper gives the relations that allow calculation of the volume of bulk material in individual sections of the auger dewaterer. The calculated values from these relationships, were verified and compared with the values read from the 3D CAD system for designing SolidWorks Premium 2012 SP 5.0 models. The percentage compression values of the loose material in the threads of differential pitch of the conical auger of the unsuitably designed auger-screw dewaterer by Advanced Metal Powders s.r.o. allowed us to define recommendations that, applied, would ensure malfunction-free operation of the auger-screw dewaterer.
\end{abstract}

Keywords: auger, wet bulk material, gravitational dewatering, stone mineral wool, worm dewaterer.

\section{INTRODUCTION}

The basic raw materials to produce stone mineral wool insulation are basalt (75 to $80 \%$ ) and slag (25 to $20 \%$ ) [1], which, after crushing and milling, are melted at high temperatures (1350 to $1450{ }^{\circ} \mathrm{C}$ ) in a furnace. After melting, these raw materials, the liquid rock flows into the fiberizing machines where very fine fibers are formed. Due to the centrifugal force, the melt droplets turn into fine fibers on rotating rollers (pulping wheels) in the blowing air stream. Cooler droplets of liquid melt can no longer stretch and fly off the disks as tiny grains [2] (so-called granules).
Waste from the production of stone mineral wool consists of two components, namely heterogeneous tufts of mineral wool (different sizes, shapes and interconnections) and mineral sand, which contains larger or smaller "stones" of socalled granules made of basalt glass [3]. These two components are separated from each other for further use of waste materials by the technological process and modified to the form required for further use.

Waste generated during the production of stone mineral wool, i.e. a mixture of two materials (mineral wool and granules from 20 to $80 \%$, respectively), is collected in water tanks (where 
the surface of mineral wool waste fibers is covered with water). Prior to a treatment process that separates one component of the raw material (mineral wool) from the other component (granules), it is necessary to reduce the waste volume (a mixture of two components) and to displace the free water from the "wet" waste.

Of the known methods of removing moisture from loose materials (physio-chemical, thermaldrying, freeze-drying and mechanical), wet waste from stone mineral wool production is dewatered mechanically. Mechanical methods of dewatering "wet" materials are based on the principles of centrifugation, pressing, filtering, vacuuming or gravity. The gravity drainage method can be implemented by (among other treatment equipment) an auger dewaterer.

Auger dewaterers allow the gradual dewatering of the "wet" bulk material, where at the end of the process the bulk material is discharged with a water content of only 15 to $20 \%$. The stable solid trough of circular cross-section of the auger dewaterer is provided with openings through which water flows out of the dewatered material, while solid particles of dewatered material are carried by the auger by slow rotation of the auger. The total length of the drainage trough is composed of cylindrical and conical parts (Fig. 4) or only cylindrical parts (Fig. 1 and Fig. 2).

Dewatering and compacting of bulk material in the auger dewatering unit is achieved in an effective pressing zone consisting of auger threads with different pitches (Fig. 1), a conically tapering auger (Fig. 2), or a combination thereof (Fig. 4).

\section{THEORETICAL CALCULATION OF THE VOLUME OF BULK MATERIAL IN INDIVIDUAL SECTIONS OF THE AUGER DEWATERER}

The auger designed by Advanced Metal Powders s.r.o. with a conical auger and threads of varied pitch showed marked wear of the auger after just a short time of operation (Fig. 3).

The Institute of Transport, Faculty of Mechanical Engineering, VŠB - Technical University of Ostrava was contacted by Advanced Metal Powders s.r.o. requesting technical assistance in designing the optimum thread pitch of an auger

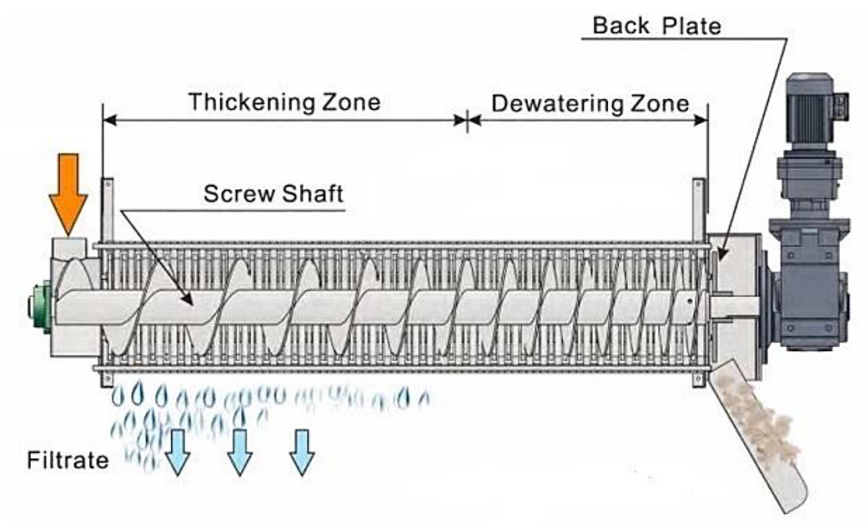

Fig. 1. The auger dewaterer with variable thread pitch of a full, cylindrical auger [5]

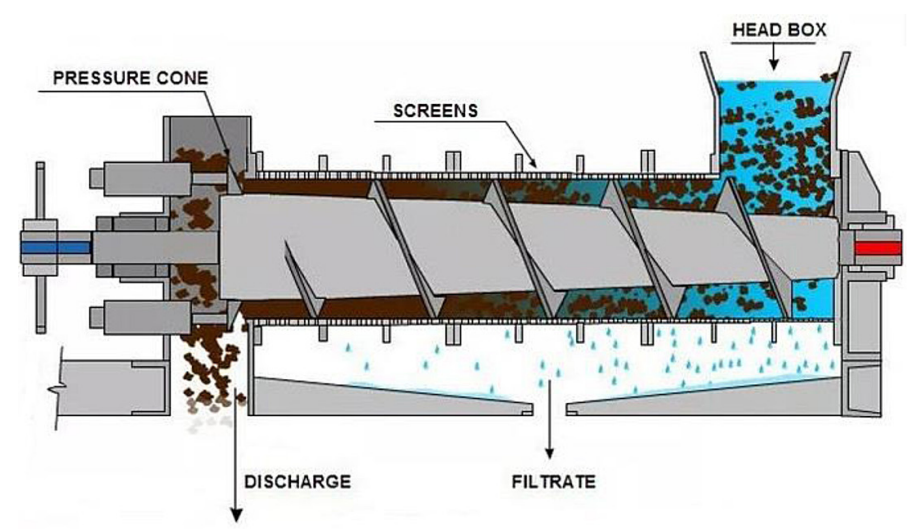

Fig. 2. Auger dewaterer with conical auger shaft and constant rise of auger screw [4] 

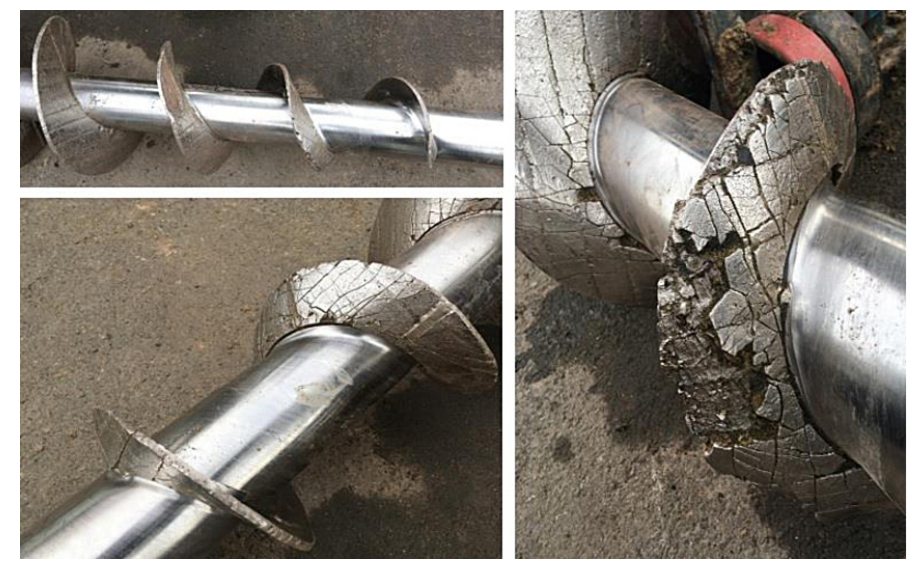

Fig. 3. Surface wear of the threads of the auger dewaterer

water separator [7], and asking for expert advice on troubleshooting and ensuring the operability of the auger dewaterer.

The primary cause of auger wear and deformation of the auger is due to the failure to take into account the different compressibility of the two components of the mixture (mineral wool - granules) to be dewatered by the auger dewaterer. When the auger shaft is rotated, the suspension consisting of two components - mineral wool and granules in a ratio from 20 to $80 \%$, respectively, is removed from the feed hopper of the worm drainage trough by the first roller auger blade (Fig. 4, section 1).

The suspension of wet bulk material is pushed by the cylindrical auger blades in section 1 to 4.1 and then moved to the tapered blades (Fig. 4, section 4.2 to 7). As the diameter of the auger with the length of the auger in section 4.2 to 7 decreases, the volume of the suspension gradually compresses, reducing its volume and increasing the pressure. The increasing pressure and decreasing volume of the suspension (wet bulk material) compresses both components of the suspension and expels water from them.

The volume of suspension, the already partially dewatered bulk material, brought (by the previous conical blades of the auger, Fig. 4 sections 4.2 to 7 ) to the 8 th section (Fig. 5) is compressed again by passing through the 8 th section of the cylindrical auger with a smaller pitch of the auger thread (than the previous auger threads).

Mineral wool can hold up to $90 \%$ water in volume and only $20 \%$ water in granules. If the suspension constitutes a granular content of more than $20 \%$, the suspension cannot be compressed to a volume that could pass through sections 4.2 to 8 of the auger dewaterer. The pressure of the suspension, compressed to the volume (Table 1) of the auger thread in sections 5 to 7 of the auger dewaterer, is extremely high and causes abrasion and deformation of the surfaces of the auger blades.

From Figure 4 it is possible to read the designed diameter of Advanced Metal Powders s.r.o auger shaft, $d_{s}=0.133 \mathrm{~m}$ and the auger thread thickness $\mathrm{t}_{\mathrm{s}}=0.01 \mathrm{~m}$. The first, second and third auger threads (Fig. 6) are of the same construction design with the chosen external $\left(\mathrm{d}_{1}\right) /$ internal diameter $\left(\mathrm{d}_{\mathrm{s}}\right)=0.44 / 0.133 \mathrm{~m}$. The pitch increase of the first, second and third threads of the auger has been chosen as $L_{1}=0.3 \mathrm{~m}$.

The volume of the $1^{\text {st }}, 2^{\text {nd }}$ and $3^{\text {rd }}$ thread of the auger $\mathrm{V}_{z 1}\left[\mathrm{~m}^{3}\right]$ in the $1^{\text {th }}, 2^{\text {th }}$ and $3^{\text {th }}$ section (Fig. 4) of the auger dewaterer can be expressed as the volume of a hollow rotating cylinder according to the relationship (1).

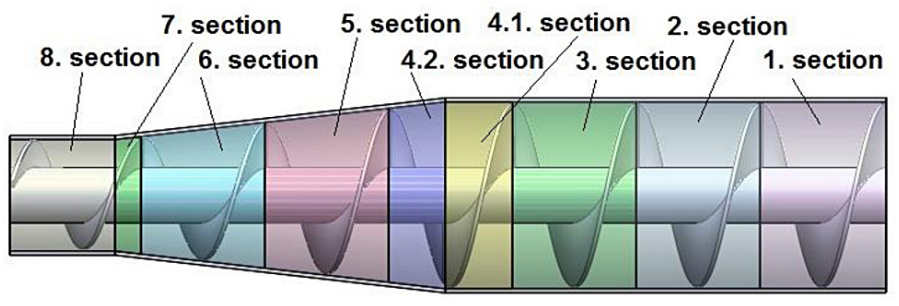

Fig. 4. Sections 1 to 8 of the auger dewaterer 


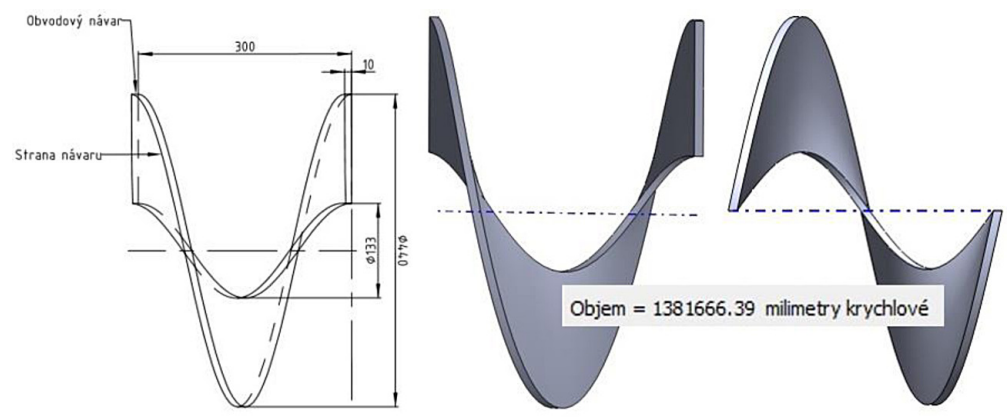

Fig. 5. Dimensions $1^{\text {th }} 2^{\text {th }}$ and $3^{\text {th }}$ of the auger thread of the auger dewaterer

$\mathrm{V}_{\mathrm{z} 1}=\frac{1}{4} \cdot \pi \cdot \mathrm{t}_{\mathrm{s}} \cdot\left(\mathrm{d}_{1}^{2}-\mathrm{d}_{\mathrm{s}}^{2}\right)=\frac{1}{4} \cdot \pi \cdot 0.01 \cdot$

$\cdot\left(0.44^{2}-0.133^{2}\right)=1.38 \cdot 10^{-3} \mathrm{~m}^{3}$

The analytically calculated volume $\mathrm{V}_{\mathrm{z1}}\left[\mathrm{dm}^{3}\right]$ (1) was verified with the "Objem" $\left[\mathrm{mm}^{3}\right][8]$ value of the created 3D model of thread of the auger (Fig. 5) in SolidWorks Premium 2012 SP 5.0.

The volume of the wet bulk material mixture in the $1^{\text {st }}$ to $3^{\text {rd }}$ section of the auger separator $V_{m 1}$ $\left[\mathrm{m}^{3}\right]$ to $\mathrm{V}_{\mathrm{m} 3}\left[\mathrm{~m}^{3}\right]$ can be expressed as the volume of the hollow rotary cylinder with an outside diameter $d_{t 1}[\mathrm{~m}]$, which is the inside diameter of the channel $\left(\mathrm{d}_{\mathrm{t} 1}=\mathrm{d}_{1}+0.01=0.45 \mathrm{~m}\right)$ and the inside diameter $\mathrm{d}_{\mathrm{s}}[\mathrm{m}]$, which is the outside diameter of the shaft of the auger according to (2).

The first part of the $4^{\text {th }}$ thread of the auger (Fig. 6) with a chosen diameter of $d_{4}=d_{1}=$ $0.44 \mathrm{~m}$, located in section 4.1 (Fig. 4) of the auger dewaterer, is designed with an auger thread pitch of $\mathrm{L}_{41}=0.164 \mathrm{~m}$.

The volume of the first part of the $4^{\text {th }}$ thread of the auger $\mathrm{V}_{\mathrm{z} 41}\left[\mathrm{~m}^{3}\right]$ in section 4.1 (Fig. 6) of the auger dewaterer, can be expressed as the volume of a hollow rotary cylinder according to the relationship (3). At an angle of $\alpha_{1}=195.6 \mathrm{deg}$ (Fig. 6) of the total angle $\alpha=360 \mathrm{deg}$ (which is defined by the circumference of the circle $\alpha=2 \cdot \pi[\mathrm{rad}]=$ $360 \mathrm{deg}$ ) the constant $\mathrm{k}_{41}=\alpha_{1} / \alpha$ [-] is set.

$$
\begin{aligned}
\mathrm{V}_{z 41}= & \mathrm{k}_{41} \cdot \frac{1}{4} \cdot \pi \cdot \mathrm{t}_{\mathrm{s}} \cdot\left(\mathrm{d}_{4}^{2}-\mathrm{d}_{\mathrm{s}}^{2}\right)=\frac{195.6}{360} \cdot \frac{1}{4} \cdot \pi \cdot \\
& \cdot 0.01 \cdot\left(0.44^{2}-0.133^{2}\right)=7.5 \cdot 10^{-4} \mathrm{~m}^{3}
\end{aligned}
$$

The volume of the transported material $\mathrm{V}_{\mathrm{m} 41}\left[\mathrm{~m}^{3}\right]$, see (4), in the first part of the $4^{\text {th }}$ thread, i.e. in section 4.1 of the auger dewaterer, can be expressed as (as the volume of a hollow rotary cylinder with an outer diameter of $\mathrm{d}_{\mathrm{t} 1}[\mathrm{~m}]$ and inner diameter of $d_{s}[m]$ ) according to the relationship (2), if in (2) we replace the thread pitch $\mathrm{L}_{1}[\mathrm{~m}]$ with $\mathrm{L}_{41}[\mathrm{~m}]$ and the volume of the auger thread $\mathrm{V}_{\mathrm{z1}}\left[\mathrm{m}^{3}\right]$ with $\mathrm{V}_{\mathrm{z} 41}\left[\mathrm{~m}^{3}\right]$.

$$
\begin{aligned}
\mathrm{V}_{\mathrm{m} 41} & =\frac{1}{4} \cdot \pi \cdot 0.164 \cdot\left(0.45^{2}-0.133^{2}\right)- \\
& -7.5 \cdot 10^{-4}=23.04 \cdot 10^{-3} \mathrm{~m}^{3}
\end{aligned}
$$

The second section of the $4^{\text {th }}$ thread of the auger (Fig. 7) of the chosen diameter $d_{4}=d_{1}=$ $0.44 \mathrm{~m}$ and $\mathrm{d}_{5}=0.409 \mathrm{~m}$, located in section 4.2 (Fig. 4) of the auger dewaterer, is designed with a pitch of $\mathrm{L}_{42}=0.136 \mathrm{~m}$ in the $2^{\text {nd }}$ part of the $4^{\text {th }}$ thread of the screw.

The volume of the second part of the $4^{\text {th }}$ section of the auger thread $\mathrm{V}_{z 42}\left[\mathrm{~m}^{3}\right]$, see (5), in section 4.2 (Fig. 4) of the auger dewaterer can be
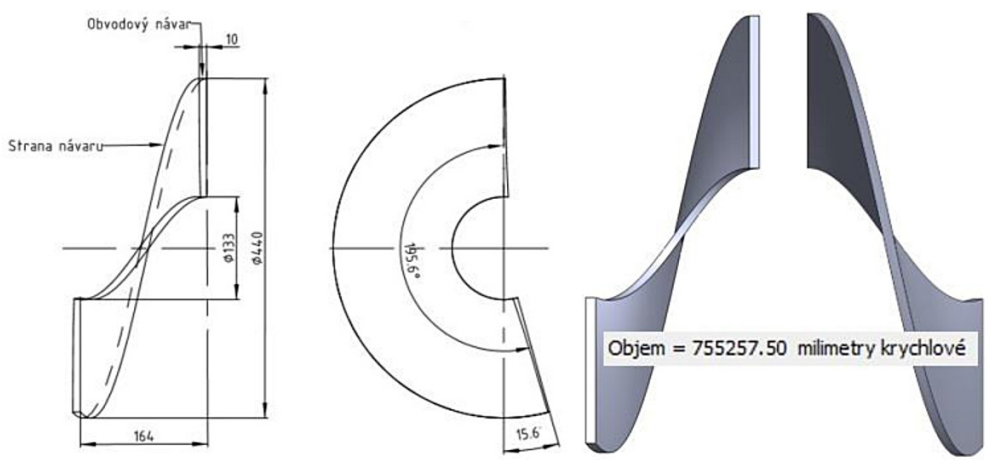

Fig. 6. Dimensions of the $1^{\text {st }}$ part of the $4^{\text {th }}$ thread of the auger screw in section 4.1 of the auger dewaterer 


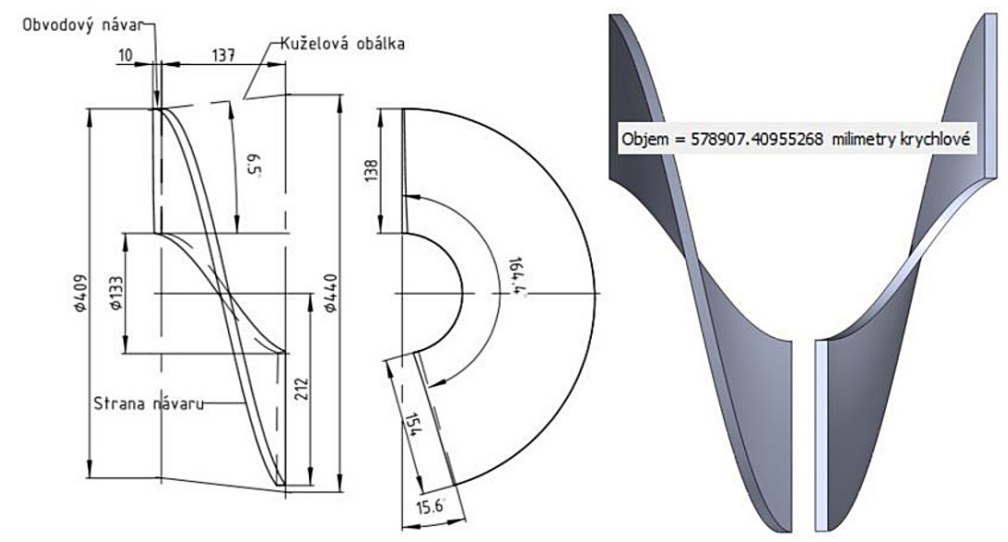

Fig. 7. Dimensions of the $2^{\text {nd }}$ part of the $4^{\text {th }}$ thread of the auger screw in section 4.2 of the auger dewaterer

expressed according to the relationship (3) under the assumption that in (3) we replace the constant $\mathrm{k}_{41}[-]$ with $\mathrm{k}_{42}[-]$ and the diameter $\mathrm{d}_{4}[\mathrm{~m}]$ with $\left(\mathrm{d}_{4}\right.$ $\left.+\mathrm{d}_{5}\right) / 2[\mathrm{~m}]$.

At an angle of $\alpha_{2}=164.4 \mathrm{deg}$ (Fig. 7) of the total angle $\alpha=360 \mathrm{deg}$, and constant $\mathrm{k}_{42}=\alpha_{2} / \alpha$ [-] is set.

$$
\begin{aligned}
& \mathrm{V}_{\mathrm{z} 42}=\left[\left(\frac{0.44+0.409}{2}\right)^{2}-0.133^{2}\right] . \\
& \cdot \frac{164.4}{360} \cdot \frac{1}{4} \cdot \pi \cdot 0.01=5.8 \cdot 10^{-4} \mathrm{~m}^{3}
\end{aligned}
$$

The volume of the transported material $\mathrm{V}_{\mathrm{m} 42}$ $\left[\mathrm{m}^{3}\right]$ in the second part of the $4^{\text {th }}$ thread, i.e. in section 4.2 of the auger dewaterer, can be expressed as the volume of a hollow vertical cone with an outer diameter $\mathrm{d}_{\mathrm{t} 1}[\mathrm{~m}]$ (the initial inner diameter of the trough with a circular cross-section) and an outer diameter $d_{t 5}[\mathrm{~m}]$, which is the inner diameter of the trough with a circular cross-section at the end of section 4.2 of the auger dewaterer, according to relationship (6).

$$
\begin{gathered}
\mathrm{V}_{\mathrm{m} 42}=\left[\left(\frac{\mathrm{d}_{\mathrm{t} 4}}{2}\right)^{2}+\frac{\mathrm{d}_{\mathrm{t} 4}}{2} \cdot \frac{\mathrm{d}_{\mathrm{t} 5}}{2}+\left(\frac{\mathrm{d}_{\mathrm{t} 5}}{2}\right)^{2}\right] . \\
\cdot \frac{1}{3} \cdot \pi \cdot \mathrm{L}_{42}-\frac{1}{4} \cdot \pi \cdot \mathrm{d}_{\mathrm{s}}^{2} \cdot \mathrm{L}_{42}-\mathrm{V}_{\mathrm{z} 42}\left[\mathrm{~m}^{3}\right] \\
\mathrm{V}_{\mathrm{m} 42}=\left[\left(\frac{0.45}{2}\right)^{2}+\frac{0.45}{2} \cdot \frac{0.419}{2}+\left(\frac{0.419}{2}\right)^{2}\right] . \\
\cdot \frac{1}{3} \cdot \pi \cdot 0.136-\frac{1}{4} \cdot \pi \cdot 0.133^{2} \cdot 0.136- \\
\quad-5.8 \cdot 10^{-4}=17.71 \cdot 10^{-3} \mathrm{~m}^{3}
\end{gathered}
$$

The fifth screw thread (Fig. 8) of the chosen diameter $\mathrm{d}_{5}=0.409 \mathrm{~m}$ and $\mathrm{d}_{6}=0.341 \mathrm{~m}$, located in section 5 (Fig. 4) of the auger dewaterer, is designed with an auger pitch of $\mathrm{L}_{5}=\mathrm{L}_{1}=0.3 \mathrm{~m}$.

The volume $5^{\text {th }}$ of the auger thread $\mathrm{V}_{z 5}\left[\mathrm{~m}^{3}\right]$, see (7), in section 5 (Fig. 4) of the auger dewaterer, can be expressed according to the relationship (1), if in (1) we replace diameter $\mathrm{d}_{1}[\mathrm{~m}]$ with $\left(\mathrm{d}_{5}+\mathrm{d}_{6}\right) / 2[\mathrm{~m}]$.

$$
\begin{aligned}
\mathrm{V}_{\mathrm{z5}} & =\left[\left(\frac{0.409+0.341}{2}\right)^{2}-0.133^{3}\right] . \\
& \cdot \frac{1}{4} \cdot \pi \cdot 0.01=9.7 \cdot 10^{-4} \mathrm{~m}^{3}
\end{aligned}
$$

The volume of the transported material $\mathrm{V}_{\mathrm{m} 5}$ $\left[\mathrm{m}^{3}\right]$, see (8), in the $5^{\text {th }}$ thread, i.e. in section 5 of the auger dewaterer, can be expressed according to the relationship (6), if in (6) we replace the outer diameter $\mathrm{d}_{\mathrm{t} 1}[\mathrm{~m}]$ with $\mathrm{d}_{\mathrm{t} 5}=\mathrm{d}_{5}+0.01[\mathrm{~m}]$ (the initial inner diameter of the trough with a circular cross-section in section 5) and an outer diameter of $d_{t 2}[\mathrm{~m}]$ with ${ }_{3}[\mathrm{~m}]$, which is the inner diameter of the trough with a circular cross-section at the end of section 5 of the auger dewaterer.

$$
\begin{aligned}
& \mathrm{V}_{\mathrm{m} 5}=\left[\left(\frac{0.419}{2}\right)^{2}+\frac{0.419}{2} \cdot \frac{0.351}{2}+\left(\frac{0.351}{2}\right)^{2}\right] . \\
& \\
& \quad \cdot \frac{\pi}{3} \cdot 0.3-\frac{\pi}{4} \cdot 0.3 \cdot 0.133^{2}- \\
&-9.7 \cdot 10^{-4}=29.91 \cdot 10^{-3} \mathrm{~m}^{3}
\end{aligned}
$$

The sixth auger thread (Fig. 9) of the chosen diameter $\mathrm{d}_{6}=0.341 \mathrm{~m}$ and $\mathrm{d}_{7}=0.272 \mathrm{~m}$, located in section 6 (Fig. 4 ) of the auger dewaterer, is designed with an auger pitch of $\mathrm{L}_{6}=\mathrm{L}_{1}=300 \mathrm{~mm}$.

The volume of the sixth auger thread $\mathrm{V}_{z 6}$ $\left[\mathrm{m}^{3}\right]$, see (9), in section 6 (Fig. 4) of the auger 


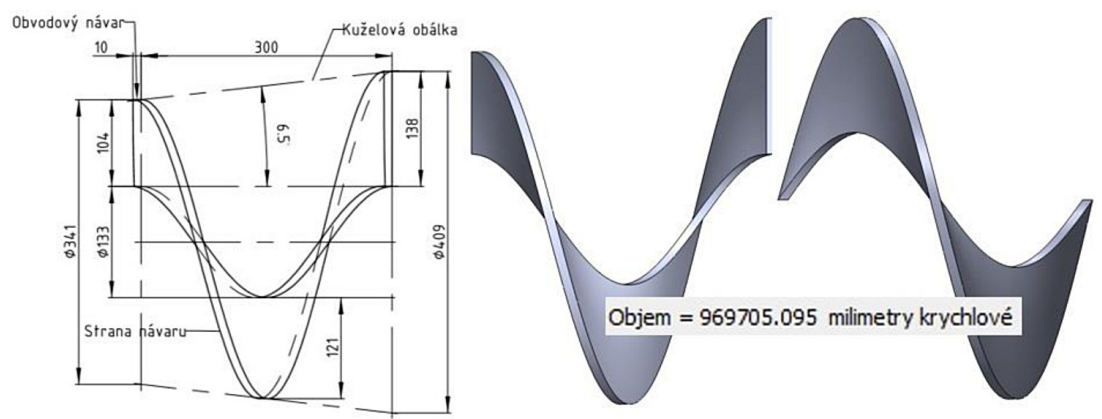

Fig. 8. Dimensions of the $5^{\text {th }}$ screw thread of the auger dewaterer

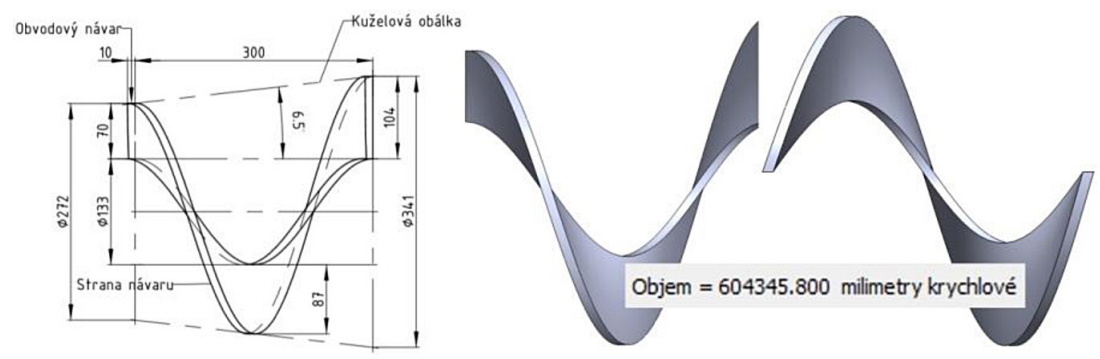

Fig. 9. Dimensions of the $6^{\text {th }}$ auger thread of the auger dewaterer

dewaterer, can be expressed according to the relationship (1), if in (1) we replace the diameter $d_{1}$ $[\mathrm{m}]$ with $\left(\mathrm{d}_{6}+\mathrm{d}_{7}\right) / 2[\mathrm{~m}]$.

$$
\begin{aligned}
\mathrm{V}_{\mathrm{z} 6}= & {\left[\left(\frac{0.341+0.272}{2}\right)^{2}-0.133^{2}\right] . } \\
& \cdot \frac{1}{4} \cdot \pi \cdot 0.01=6 \cdot 10^{-4} \mathrm{~m}^{3}
\end{aligned}
$$

The volume of the transported material $\mathrm{V}_{\mathrm{m} 6}$ $\left[\mathrm{m}^{3}\right]$, see $(10)$, in the $6^{\text {th }}$ thread, i.e. in section 6 of the auger dewaterer can be expressed according to the relationship (6), if we replace in (6) the outer diameter $d_{t 1}[m]$ with $d_{t 6}[m]$ (the initial inner diameter of the trough with a circular crosssection in section 6) and the outer diameter $\mathrm{d}_{\mathrm{t} 2}[\mathrm{~m}]$ with $d_{t 7}[m]$, which is the inner diameter of the trough with a circular cross-section at the end of section 6 of the auger dewaterer.

$$
\begin{aligned}
\mathrm{V}_{\mathrm{m} 6}=\left[\left(\frac{0.351}{2}\right)^{2}+\frac{0.351}{2} \cdot \frac{0.282}{2}+\left(\frac{0.282}{2}\right)^{2}\right] . \\
\quad \cdot \frac{\pi}{3} \cdot 0.3-\frac{1}{4} \cdot \pi \cdot 0.133^{2} \cdot 0.3- \\
\quad-6 \cdot 10^{-4}=19.03 \cdot 10^{-3} \mathrm{~m}^{3}
\end{aligned}
$$

The seventh auger thread (Fig. 10) of the chosen diameter $\mathrm{d}_{7}=0.272 \mathrm{~m}$ and $\mathrm{d}_{8}=0.258 \mathrm{~m}$, located in section 7 (Fig. 4) of the auger dewaterer, is designed with a pitch of $\mathrm{L}_{7}=63 \mathrm{~mm}$.

The volume of the seventh auger thread $\mathrm{V}_{\mathrm{z} 7}$ $\left[\mathrm{m}^{3}\right]$, see (11), in section $7^{\text {th }}$ (Fig. 3) of the auger dewaterer can be expressed according to the relationship (3) under the assumption that in (3) we replace the constant $\mathrm{k}_{41}[-]$ with $\mathrm{k}_{7}[-]$ and the diameter $\mathrm{d}_{4}[\mathrm{~m}]$ with $\left(\mathrm{d}_{7}+\mathrm{d}_{8}\right) / 2[\mathrm{~m}]$. At an angle of $\alpha_{3}=75.6 \mathrm{deg}$ (Fig. 10) of the total angle $\alpha=$ $360 \mathrm{deg}$ (which is defined by the circumference of the circle $\alpha=2 \cdot \pi[\mathrm{rad}]=360 \mathrm{deg}$ ) the constant $\mathrm{k}_{7}$ $=\alpha_{3} / \alpha[-]$ is set.
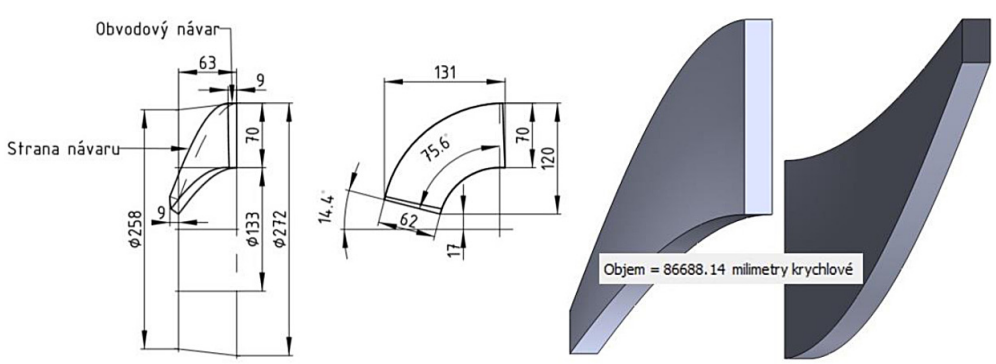

Fig. 10. Dimensions of the $7^{\text {th }}$ auger thread of the auger dewaterer 


$$
\begin{gathered}
\mathrm{V}_{\mathrm{z} 7}=\left[\left(\frac{0.272+0.258}{2}\right)^{2}-0.133^{2}\right] \\
\cdot \frac{75.6}{360} \cdot \frac{\pi}{4} \cdot 0.01=9 \cdot 10^{-5} \mathrm{~m}^{3}
\end{gathered}
$$

The volume of the transported material $\mathrm{V}_{\mathrm{m} 7}$ $\left[\mathrm{m}^{3}\right]$, see $(12)$, in the $7^{\text {th }}$ thread, i.e. in section 7 of the auger dewaterer can be expressed according to the relationship (6), if in (6) we replace the outer diameter $d_{t 1}[m]$ with $d_{t 7}[m]$ (initial inner diameter of the trough with a circular cross-section in section 7) and the outer diameter $d_{t 2}[\mathrm{~m}]$ with $d_{t 8}[\mathrm{~m}]$, which is inner diameter of the trough with a circular cross-section at the end of section 7 of the auger dewatere.

$$
\begin{aligned}
\mathrm{V}_{\mathrm{m} 7}= & {\left[\left(\frac{0.272}{2}\right)^{2}+\frac{0.272}{2} \cdot \frac{0.258}{2}+\left(\frac{0.258}{2}\right)^{2}\right] . } \\
& \cdot \frac{\pi}{3} \cdot 0.063-\frac{1}{4} \cdot \pi \cdot 0.133^{2} \cdot 0.063- \\
& \quad-9 \cdot 10^{-5}=2.81 \cdot 10^{-3} \mathrm{~m}^{3}
\end{aligned}
$$

The eighth auger thread (Fig. 11) of the chosen diameter $\mathrm{d}_{8}=\mathrm{d}_{7}=0.258 \mathrm{~m}$, located in the $8^{\text {th }}$ section (Fig. 4 ) of the auger dewaterer, is designed with a screw pitch of $\mathrm{L}_{8}=0.25 \mathrm{~m}$.

The volume $8^{\text {th }}$ thread of the auger $\mathrm{V}_{z 8}\left[\mathrm{~m}^{3}\right]$, see (13), in section 8 (Fig. 11) of the auger dewaterer, can be expressed according to relationship (1), under the assumption that in (1) we replace the diameter $d_{1}[\mathrm{~m}]$ with $d_{8}[\mathrm{~m}]$.

$$
\begin{gathered}
\mathrm{V}_{\mathrm{z} 8}=\left(0.258^{2}-0.133^{2}\right) . \\
\cdot \frac{1}{4} \cdot \pi \cdot 0.01=3.8 \cdot 10^{-4} \mathrm{~m}^{3}
\end{gathered}
$$

The volume of the transported material $\mathrm{V}_{\mathrm{m} 8}$ $\left[\mathrm{m}^{3}\right]$, see (14), in the $8^{\text {th }}$ section of the auger dewaterer can be expressed as (2), if in (2) we replace $\mathrm{dt}_{1}[\mathrm{~m}]$ with $\mathrm{d}_{\mathrm{t} 8}[\mathrm{~m}]$.

$$
\begin{aligned}
\mathrm{V}_{\mathrm{m} 8}= & \frac{1}{4} \cdot \pi \cdot 0.25 \cdot\left(0.268^{2}-0.133^{2}\right)- \\
& -3.8 \cdot 10^{-4}=10.56 \cdot 10^{-3} \mathrm{~m}^{3}
\end{aligned}
$$

\section{COMPRESSION OF THE MIXTURE OF BULK MATERIAL IN INDIVIDUAL SECTION OF THE AUGER DEWATERER}

The auger shaft transfers the torque from the motor to the screw [9]. At known rotations of the auger screw, $\mathrm{n}_{\mathrm{s}}\left[\mathrm{s}^{-1}\right]$, and with a pitch of the auger thread $\mathrm{s}[\mathrm{m}]$, it is possible to determine, according to the relationship (15), the speed of the motion $\mathrm{v}_{\mathrm{m}}[\mathrm{m} / \mathrm{s}]$ of the material layer $[8,9]$ along the trough of the auger dewaterer.

$$
\mathrm{v}_{\mathrm{m}}=\mathrm{s} \cdot \mathrm{n}_{\mathrm{s}}\left[\mathrm{m} \cdot \mathrm{s}^{-1}\right]
$$

In the component sections " $i$ " of the auger dewaterer, compression of the wet bulk material occurs as it is moved by the auger along the trough at a speed of $v_{m}[\mathrm{~m} / \mathrm{s}]$, which means shrinkage of the volume $\mathrm{V}_{\mathrm{mi}}\left[\mathrm{m}^{3}\right]$ of the bulk material, resulting in the expressing of water in the given volume $\mathrm{V}_{\mathrm{mi}}\left[\mathrm{m}^{3}\right]$.

With respect to the design of the auger by Advanced Metal Powders s.r.o., whose screw is clockwise and conical in sections No. 4.1 to 7 (Fig. 4), a percentage compression of the volume of bulk material, $\mathrm{k}_{\mathrm{p} 4}[\%]$, takes place in section 4 (sum of sections 4.1 and 4.2), see relationship (16).

$$
\begin{gathered}
\mathrm{k}_{\mathrm{p} 4}=\left(1-\frac{\mathrm{V}_{\mathrm{m} 4.1}+\mathrm{V}_{\mathrm{m} 4.2}}{\mathrm{~V}_{\mathrm{m} 1}}\right) \cdot 100= \\
=\left(1-\frac{23.04+17.71}{42.17}\right) \cdot 100=3.37 \%
\end{gathered}
$$

In sections $5^{\text {th }}, 6^{\text {th }}$ and $7^{\text {th }}$ and in section 8 (Fig. 4) the percentage compression of volume

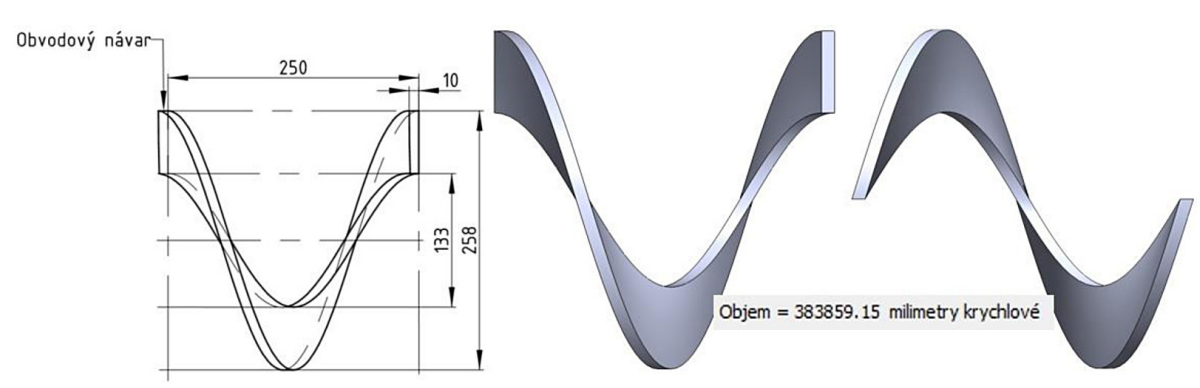

Fig. 11. Dimensions of the $8^{\text {th }}$ auger thread of the auger dewaterer 
$\mathrm{k}_{\mathrm{pi}}[\%]$ of bulk material is shown in Table 1 . The overall percentage compression of the material (related to the volume $\mathrm{V}_{\mathrm{m} 1}\left[\mathrm{~m}^{3}\right]$ of wet bulk material in section no. 1) $\mathrm{k}_{\mathrm{pc}}[\%]$ is calculated in the relationship (17).

$$
\begin{gathered}
\mathrm{k}_{\mathrm{pc}}=\left(1-\frac{\mathrm{V}_{\mathrm{m} 8}}{\mathrm{~V}_{\mathrm{m} 1}}\right) \cdot 100= \\
=\left(1-\frac{10.56}{42.17}\right) \cdot 100=74.96 \%
\end{gathered}
$$

The bulk material from which water is pressed out in the auger dewaterer is a mixture of two materials: mineral wool (maximum compressibility of $90 \%$ ) and granules from the production of mineral wool (maximum compressibility of $20 \%$ ) (Fig. 13).

Mineral wool is represented in the volume of the wet bulk material and granules of $20-80 \%$, respectively. The volume share of mineral wool and granulate (in unit volume $\mathrm{V}=1 \mathrm{~m}^{3}$ ) ranged from 0.2 to $0.8 \mathrm{~m}^{3}$.
From (17) it follows that the volume of bulk material $\mathrm{Vm}_{8}=10.56 \mathrm{dm}^{3}$ extruded from the end section of the auger dewaterer (see $8^{\text {th }}$ section on Figure 3) is compressed to $25.04 \%$ of its initial volume $\mathrm{V}_{\mathrm{m} 1}=42.17 \mathrm{dm}^{3}$ by passage through the component sections (overall percentage compression $\left.\mathrm{k}_{\mathrm{pc}}=74.96 \%\right)$.

From Table 2 it follows that only $80 \%$ by volume of mineral wool and $20 \%$ by volume of granules in bulk material entering the hopper of the auger dewaterer, the total percent compression is $\mathrm{k}_{\mathrm{m} 7}=76 \%$. All other percentages of mineral wool and granules in the bulk material mixture make it impossible to compress the volume of the mixture to a volume such that it passes through sections of the auger. This causes pressure on the threads (farther from the auger dewaterer filling point) from the supply of incompressible material and, due to the high friction and forces applied, wears the contact surfaces of the auger with the bulk material (Fig. 3).

To avoid damaging the construction design of the auger according to Figure 3, it is necessary to

Table 1. The volume of bulk material and compression of bulk material in the $\mathrm{i}^{\text {th }}$ section of the screw of the

\begin{tabular}{|c|c|c|c|c|c|c|}
\hline $\mathrm{i}$ & $V_{i}$ & $\mathrm{~V}_{\mathrm{si}}$ & $\mathrm{V}_{\mathrm{mi}}$ & $\mathrm{k}_{\mathrm{i}}$ & $\mathrm{k}_{\mathrm{pi}}$ & $\mathrm{k}_{\mathrm{pc}}$ \\
\hline$[-]$ & \multicolumn{3}{|c|}{$10^{-3}\left[\mathrm{~m}^{3}\right]$} & {$[-]$} & \multicolumn{2}{|c|}{ [\%] } \\
\hline 1 & \multirow{3}{*}{43.55} & \multirow{3}{*}{1.38} & \multirow{3}{*}{42.17} & & & \\
\hline 2 & & & & & & \\
\hline 3 & & & & & & \\
\hline 4.1 & 23.8 & 0.76 & 23.04 & & & \\
\hline 4.2 & 18.29 & 0.58 & 17.71 & & & \\
\hline $4.1+4.2$ & 42.09 & 1.34 & 40.75 & 0.97 & 3.37 & \\
\hline 5 & 30.88 & 0.97 & 29.91 & 0.73 & 26.60 & \\
\hline 6 & 19.63 & 0.60 & 19.03 & & & \\
\hline 7 & 2.90 & 0.09 & 2.81 & & & \\
\hline $6+7$ & 22.53 & 0.69 & 21.84 & 0.73 & 26.98 & \\
\hline 8 & 10.94 & 0.38 & 10.56 & 0.48 & 51.65 & 74.96 \\
\hline
\end{tabular}
auger dewaterer

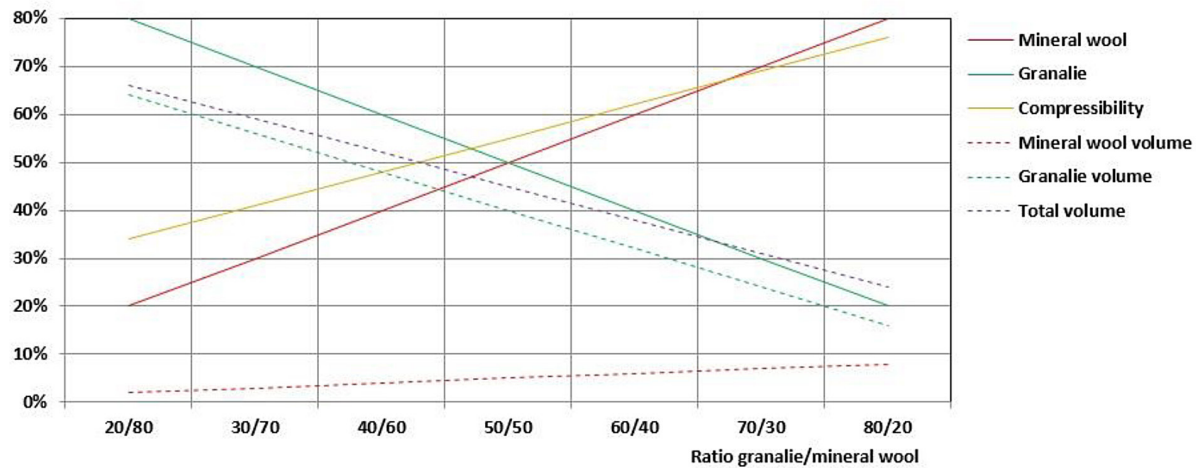

Fig. 12. Compressibility of material volume depending on the share of mineral wool and granules in a suspension volume 
Table 2. Mineral wool (with a compression of 90\%) and granules (with a compression of 20\%) represented in a mixture of 20 to $80 \%$

\begin{tabular}{|c|c|c|c|c|c|c|c|c|c|}
\hline \multirow{3}{*}{ j } & $V_{G(\%)}$ & $\mathrm{V}_{\mathrm{V}(\%)}$ & $V_{G(V)}$ & $V_{v(v)}$ & $\mathrm{V}_{\mathrm{G}(\mathrm{V}) \min }$ & $\mathrm{V}_{\mathrm{V}(\mathrm{V}) \min }$ & \multirow{3}{*}{$\frac{\underset{\min }{\mathrm{V}_{\mathrm{G}(\mathrm{m} \min +}} \mathrm{V}_{\mathrm{V}(\mathrm{V})}}{\left[\mathrm{m}^{3}\right]}$} & \multirow{3}{*}{$\begin{array}{l}\mathrm{k}_{\mathrm{mj}} \\
{[\%]}\end{array}$} & \multirow{3}{*}{$\frac{\mathrm{k}_{\mathrm{sj}}}{[-]}$} \\
\hline & \multirow{2}{*}{\multicolumn{2}{|c|}{ [\%] }} & \multirow{2}{*}{\multicolumn{2}{|c|}{$\left[\mathrm{m}^{3}\right]$}} & \multicolumn{2}{|c|}{$\left[\mathrm{m}^{3}\right]$} & & & \\
\hline & & & & & $20 \% V_{G(V)}$ & $90 \% V_{G(V)}$ & & & \\
\hline 1 & 80 & 20 & 0.8 & 0.2 & $0.8 .0 .8=0.64$ & $0.1 .0 .2=0.02$ & 0.66 & 34 & 0.36 \\
\hline 2 & 70 & 30 & 0.7 & 0.3 & $0.8 \cdot 0.7=0.56$ & $0.1 .0 .3=0.03$ & 0.59 & 41 & 0.41 \\
\hline 3 & 60 & 40 & 0.6 & 0.4 & $0.8 .0 .6=0.48$ & $0.1 .0 .4=0.04$ & 0.52 & 48 & 0.46 \\
\hline 4 & 50 & 50 & 0.5 & 0.5 & $0.8 .0 .5=0.40$ & $0.1 .0 .5=0.05$ & 0.45 & 55 & 0.53 \\
\hline 5 & 40 & 60 & 0.4 & 0.6 & $0.8 .0 .4=0.32$ & $0.1 .0 .6=0.06$ & 0.38 & 62 & 0.63 \\
\hline 6 & 30 & 70 & 0.3 & 0.7 & $0.8 \cdot 0.3=0.24$ & $0.1 .0 .7=0.07$ & 0.31 & 69 & 0.77 \\
\hline 7 & 20 & 80 & 0.2 & 0.8 & $0.8 \cdot 0.2=0.16$ & $0.1 .0 .8=0.08$ & 0.24 & 76 & 1.00 \\
\hline
\end{tabular}

ensure that the quantity of mixture $\mathrm{Q}_{\mathrm{sm}(\mathrm{j})}\left[\mathrm{m}^{3} / \mathrm{s}\right]$ of the bulk material fed into the hopper in precise doses according to the relationship (18).

$$
\begin{gathered}
\mathrm{Q}_{\mathrm{sm}(\mathrm{j})}=\mathrm{Q}_{\mathrm{sm}} \cdot \mathrm{k}_{\mathrm{sj}}= \\
=\frac{\pi \cdot \mathrm{d}_{\mathrm{t} 1}^{2}}{4} \cdot \mathrm{v}_{m} \cdot \mathrm{k}_{\mathrm{sj}}\left[m^{3} \cdot \mathrm{s}^{-1}\right]
\end{gathered}
$$

\section{CONCLUSION}

The paper deals with an auger dewaterer (i.e. press) of wet bulk material, with a conically shaped auger and a sieve channel with a cylindrical cross-section with three main zones: a) inlet, b) pressing, compaction and drainage and c) outlet. The volume of the bulk material added is reduced in the compacting and dewatering zone by the threads of the conically - shaped auger dewaterer. Reducing the volume of material in sections 4.1 to 8 of the auger dewaterer results in its compacting and dewatering. The compacting of the bulk material is largely dependent on the proportion of granules in the volume of suspension of the wet bulk material conveyed by the auger dewaterer. The length of time for passage of the bulk material through the auger dewaterer is dependent on the auger speed, which is adjustable.

The principle of the drainage of waste (a mixture of mineral wool tufts and granules) from the production of stone mineral wool is that the electric gear-driven auger shaft rotates in a perforated trough which can be inclined up to an angle of 30 degrees. Wet tufts of mineral wool with granular admixture fall through the hopper onto the rotating auger, roll along the walls of the auger separator trough and move in the direction from the hopper to the discharge opening.
The paper presents theoretically-calculated volumes of wet loose suspension in component sections of an auger dewaterer.

Based on the calculations obtained and considerations, it follows that for the avoidance of significant wear of the auger and consequent damage to the auger and drainage trough, it is necessary to either accurately dose the supplied amount of wet bulk material suspension into the auger drain hopper or to adjust the auger speed to achieve the required velocity of movement of the material layer along the auger drainage trough.

\section{Acknowledgements}

This work has been supported by The Ministry of Education, Youth and Sports of the Czech Republic from the Specific Research Project SP2020/90.

\section{REFERENCES}

1. Badalova M. and Dobrovolna J. Recyklace minerálnich vláken z odpadu. In: 5. Odborna konference doktorského studia $\mathrm{s}$ mezinárodni účasti. Brno, 2003, 17-20, (In Czech).

2. Durna A., Fries J., Hrabovsky L., Sliva A. and Zarnovsky J. Research and development of laser engraving and material cutting machine from 3D printer. Management Systems in Production Engineering, 28(1), 2020, 47-52.

3. Hrabovsky L., Kulka J. and Michalik P. Device for determining the adhesion coefficient at the slippage point. IOP Conference Series: Materials Science and Engineering, 603 (5), 2019, 1-7.

4. Kulka J., Mantic M., Kopas M., Faltinova E. and Hrabovsky L. Simulation-expertise analysis of ropes used in the horizontal belaying system. Scientific Journal of Silesian University of Technol- 
ogy. Series Transport, 103, 2019, 53-67.

5. Alibaba Producs. Available at: https://www.alibaba.com/product-detail/meat-canning-sewage-treatment-plant-sludge_60547584989.html (Access: 21.05.2020).

6. Dewatering Squeezer. Available at: http:// shredding-machine.com/index.php/product/dewateringscrew-press/ (Access: 28.05.2020).

7. Hubercs-CZ. Available at: https://www. hubercs. cz/cz/produkty/zpracovani-kalu/odvodneni.html (in Czech) (Access: 28.05.2020).

8. Mineralni Vata. Available at: http://www.stavebniny-rychle.cz/jak-probiha-vyroba-mineralnivlny-znacky-isover.html (in Czech) (Access: 20.02.2020).

9. stavba-tzb. Available at: https://stavba.tzb-info.cz/ tepelne-izolace/11827-vyuziti-odpadnich-materialu-z-vyroby-mineralni-vlny-do-stavebnich-hmot (in Czech) (Access: 17.04.2020). 